\title{
Footwear buying behaviour among college girls
}

\section{Komal Lakhara and Rupal Babel}

See end of the paper for authors' affiliations

\section{Komal Lakhara}

Department of Textiles and Apparel Designing, College of Community and Applied

Sciences, Maharana Pratap

University of Agriculture and

Technology, Udaipur (Rajasthan)

India

Email : komallakshkar@gmail.

com
Received: 08.07.2019; Revised: 16.10.2019; Accepted: 30.10.2019

ABSTRACT : The footwear fashion plays a dominant role in determining footwear consumerism. Over the past decade, India has been witnessing a rising trend of consumer orientation towards lifestyle and fashion. Half of the consumers of India are youth. Youth is the most diverse, challenging and unpredictable demographic group to know about buying behaviour. Footwear is an essential part of youth's personality and individuality. Young consumers are very demanding about their footwear fashion and trends, they are ready to expend on footwear. Consumer behaviour can be defined as the process of thoughts, feelings and actions related to the utilization process. The present study was done to find out footwear buying behaviour among college going girls (18-25 years) studying in three constituent colleges of Maharana Pratap University of Agriculture and Technology. 60 girls from each College were selected by the random method. The aim of present investigation was to find footwear buying behaviour of college girls.

KEY WORDS: Footwear, Fashion, Consumer, Buying behaviour, Purchase

- HOW TO CITE THIS PAPER : Lakhara, Komal and Babel, Rupal (2019). Footwear buying behaviour among college girls. Asian J. Home Sci., 14 (2) : 334-337, DOI: 10.15740/HAS/AJHS/14.2/334-337. Copyright@ 2019: Hind Agri-Horticultural Society. 